\title{
Vitenskap og fornuft - og følelser
}

\author{
I det nye helsemagasinet VOF (vitenskap \& fornuft) kan man lese om lavkarbodiett og alternative behandlings- \\ former. Redaksjonen legger ikke skjul på sine posisjoner. Her er det noe for enhver smak og mye leger vil \\ stille seg skeptisk til. Men mye er også tankevekkende og inspirerende.
}

I sommer leste jeg de første åtte numrene av helsemagasinet VOF (vitenskap \& fornuft), dvs. fra nr. 1/2010 til nr. 4/2011. Redaksjonen består av en utbrytergruppe fra det konkurrerende magasinet Mat \& Helse. Det er disse utgiverne, med Dag Viljen Poleszynski i spissen, som spurte om jeg kunne tenke meg å skrive om bladet deres. Kanskje håpet de på en forholdsvis balansert omtale, fordi de kjenner meg som en person som ikke så lett blir overmannet av følelser.

\section{Opposisjon og referanser}

Magasinets redaktører legger ikke skjul på at de er - og ønsker å være - i opposisjon. De går høyt på banen med en kritisk artikkel om statlige kostråd og Universitetet i Oslo, som «... inntil nylig [har] hatt monopol på utdanning av ernæringsfysiologer, som er blitt opplært til å tenke slik ledelsen har bestemt». Videre at det ikke er «... uvanlig at forskere henviser til forskning fra miljøer hvor de finner synspunkter de selv deler, til og med publikasjoner de selv har skrevet».

Her skyter nok redaksjonen seg selv $i$ foten. Alle som forsker vet at det er normalt og helt legitimt å referere synspunkter man selv deler og å vise til egen forskning. Spørsmålet er heller hvor selektiv man er, dvs. om man bevisst unnlater å vise til forskning som ikke støtter ens synspunkter. Dette er et stort problem som etter min oppfatning er blitt noe mindre etter at moderne datateknologi har gjort det mulig å filtrere og sortere store mengder publikasjoner og å lage hierarkiske systemer basert på metodiske prinsipper. Både Legemiddelverket og Nasjonalt kunnskapssenter for helsetjenesten er, i likhet med tilsvarende institusjoner i andre land, uttrykk for økt offentlig interesse og ansvar for å finne og anvende rett og best kunnskap.

Men dessverre er det ikke helt så enkelt heller. Mange viktige helsespørsmål lar seg ikke besvare entydig gjennom systematiske oversikter eller randomiserte, kontrollerte studier. Og selv om det foreligger dokumentasjon for at én spesiell behandling er den beste, er det ikke dermed sagt at alle leger følger den (1). I VOF (vitenskap \& fornuft) er det mange referanser, ja utgiverne legger avgjørende vekt på at alle påstander skal belegges med referanser. Leseren må her som ellers - ta et ansvar for å vurdere hvor relevante og solide referansene er.

Noen ganger henviser VOF (vitenskap \& fornuft) også til publikasjoner som viser

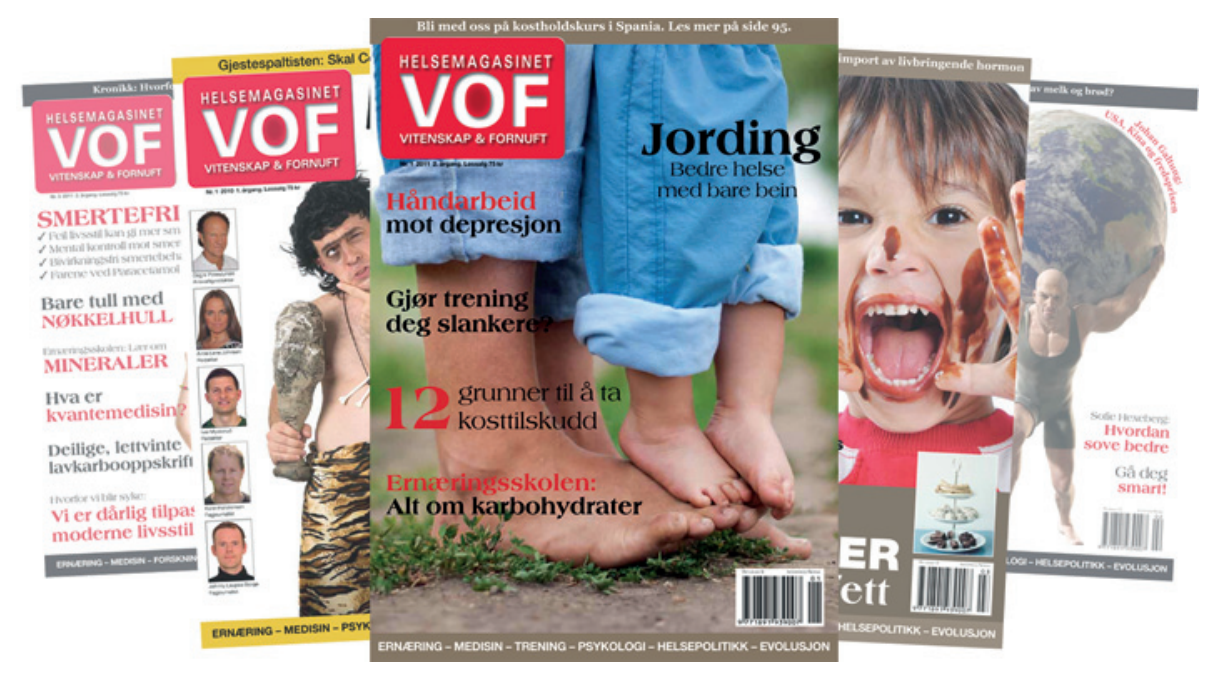

andre ting enn det redaksjonen står for selv, eller det nevnes at noen funn er basert på små eller dårlige studier og derfor må tas med forbehold. Dette er en av de viktigste grunnene til at du bør vurdere et abonnement - det finnes neppe noen annen norsk kilde som gir deg så god oversikt over den «alternative» litteraturen.

\section{Steinalderkost og lavkarbo}

Et annet utsagn som dukker opp allerede i nr. 1/2010, er at «sykeligheten - særlig utviklingen av fedme og diabetes - har økt jevnt og trutt de siste tiårene til tross for (eller kanskje snarere på grunn av) de rådene statlige myndigheter har gitt». Utsagnet gjentas i forskjellige varianter i omtrent hvert nummer. Dette er sakens kjerne: Skyldes fedmeepidemien at folk ikke følger myndighetenes råd, eller kan det tenkes at rådene er feil? Noen fagfolk har begynt å stille dette spørsmålet, men en slik standpunktendring sitter nok langt inne. Etter mitt skjønn må det vel være i alles interesse at befolkningen blir friskere og mindre overvektig? Vi trenger vel ikke å vente i det uendelige med å finne ut hvem som hadde «rett»-da er det jo likevel for sent.

Hovedbudskapet i VOF (vitenskap \& fornuft) er enkelt: Fordi menneskekroppen fysiologisk fremdeles befinner seg på steinalderstadiet, ødelegger vi den ved å fylle oss med moderne, karbohydratrik mat. Kroppen vil gjerne lage det meste av de nødvendige karbohydratene selv, fra proteiner og særlig fra fett. VOF (vitenskap \& fornuft) mener at en naturlig fordeling av hovednæringsstof- fene målt i energiprosent er 5-10\% E fra karbohydrater, $10-15 \% \mathrm{E}$ fra proteiner og $75-80 \%$ E fra fett. Myndighetenes anbefaling er henholdsvis $50-60 \% \mathrm{E}, 10-20 \% \mathrm{E}$ og 5-35\% E. VOF (vitenskap \& fornuft) mener det viktigste er å unngå for mye karbohydrater, myndighetenes standpunkt er at man ikke må få i seg for mange kalorier.

Det går an å se på VOF (vitenskap \& fornuft) og dets forkjempere for lavkarbokost som en gruppe i et omfattende naturlig eksperiment, der kontrollgruppen er dem med vanlig kosthold og endepunktet metabolsk syndrom - kontrollert for fysisk aktivitet. Dette eksperimentet er vi i full gang med under mottoet «the proof of the pudding lies in the eating». Det går knapt en dag uten at jeg treffer noen som er opptatt av lavkarbodiett og kan berette om betydelig vektreduksjon og et bedre liv. Når denne omtalen skrives, i oktober 2011, er aviser og TV mer overfylte av lavkarbostoff enn noensinne.

Jeg kan ikke skjønne annet enn at et slikt forsøk representerer en vinn-vinn-situasjon for helsemyndighetene. Det må da være viktigere $a t$ fedmeepidemien stagges enn hvordan folk flest blir kvitt sine kilo. Påpekninger fra fagmedisinsk hold om at alternativt kosthold, kosttilskudd eller forskjellige naturmedisinske produkter kan være skadelige eller farlige, er selvsagt viktig. Men vi må ikke glemme at også mange i sin tid anerkjente legemidler og behandlingsopplegg etter hvert viste seg å være uvirksomme eller sågar skadelige. Dette avspeiles bl.a. i store erstatningsbeløp og straffegebyrer som den farmasøytiske 
industrien har måttet betale etter å ha tjent store penger på legemidler som etter hvert viste seg å ha skadelig effekt.

\section{Flere alternativer}

Men VOF (vitenskap \& fornuft) handler om mye mer enn steinalderkost og lavkarbo. Her kan du bl.a. lese om megavitamindoser, hvordan du ved å jorde deg (med jordledning) kan få bedre helse og bedre søvn, at vann ikke bare er vann (av betydning for forståelsen av homøopatiens mulige virkemåter) og om hvordan bakterier, medikamenter, celler og organer har sine egne elektromagnetiske frekvensspektre som kan påvirkes til å gi mindre sykdom og bedre helse (såkalt kvantemedisin). Du kan også lese om hvordan sukkerindustrien og matvarekjedene ikke er et hakk bedre enn alkoholindustrien og tobakksindustrien med sin skruppelløse markedsføring.

Her er det med andre ord noe for enhver smak og helt klart mye som leger vil stille seg skeptisk til - ut ifra sine kliniske erfaringer og sin kunnskap.

Påfallende mange av historiene i $V O F$ (vitenskap \& fornuft) om det nye, det glemte eller det forskjellige begynner med en lege eller forsker som gjorde en oppdagelse som ikke ble anerkjent av vedkommendes kolleger, men hvor hun eller han likevel ikke ga seg. Ofte handlet det om erfaring på egen kropp. Slike historier har vi også flere av innen akademisk medisin, f.eks. Semmelweiss og den australske nobelprisvinneren Barry Marshall, som drakk en Helicobacter pylori-kultur for å vise at bakterien overlevde i magesyren (2).

I VOF (vitenskap \& fornuft) presenteres de aller fleste alternative synspunktene og prinsippene på en lettfattelig og populærvitenskapelig måte, uten at forfatterne legger skjul på sin egen posisjon. For meg er dette både underholdende, tankevekkende $\mathrm{og}$ inspirerende. Noen ganger måtte jeg riste begeistret på hodet, for eksempel av historien om hvordan fotballagene Strømsgodset og Odd Grenland forbedret sin listeplassering etter at de kollektivt la om kostholdet til mye fett og lite karbohydrater.

Min oppfordring til nasjonale eksperter på kosthold, kvantemedisin og mobilstråling: Skriv motinnlegg - på sak og ikke på person! Utfordre redaksjonen til duell på den akademiske arenaen! Gled dere over at budskapet sannsynligvis har fått bort flere overflødige norske kilo enn det rådene til Nasjonalt råd for ernæring har.

\section{Olaf Gjerløw Aasland}

olaf.aasland@legeforeningen.no

Legeforeningens forskningsinstitutt

Olaf Gjerløw Aasland (f. 1944) er leder av Legeforeningens forskningsinstitutt og professor ved Avdeling for helseledelse og helseøkonomi, Institutt for helse og samfunn, Universitetet i Oslo. Han forsker bl.a. på legenes helse og livsstil.

Ingen oppgitte interessekonflikter.

Litteratur

1. Ulvenes LV, Aasland OG, Nylenna M et al. Norwegian physicians' knowledge of and opinions about evidence-based medicine: cross-sectional study. PlosONE 2009; 4: e7828.

2. Marshall BJ, Goodwin CS, Warren JR et al. Prospective double-blind trial of duodenal ulcer relapse after eradication of Campylobacter pylori. Lancet 1988; 2: 1437-42.

Mottatt 29.8. 2011, første revisjon innsendt 7.10 2011, godkjent 13.10. 2011. Medisinsk redaktør Petter Gjersvik. 